\title{
The Dual World Polity: Fragmentation and Integration in the Network of Intergovernmental Organizations
}

\section{Citation}

Beckfield, Jason. 2008. "The Dual World Polity: Fragmentation and Integration in the Network of Intergovernmental Organizations." Social Problems 55 (3) (August): 419-442.

\section{Published Version}

doi:10.1525/sp.2008.55.3.419

\section{Permanent link}

http://nrs.harvard.edu/urn-3:HUL.InstRepos:12211468

\section{Terms of Use}

This article was downloaded from Harvard University's DASH repository, and is made available under the terms and conditions applicable to Other Posted Material, as set forth at http:// nrs.harvard.edu/urn-3:HUL.InstRepos:dash.current.terms-of-use\#LAA

\section{Share Your Story}

The Harvard community has made this article openly available. Please share how this access benefits you. Submit a story.

Accessibility 


\title{
The Dual World Polity: Fragmentation and Integration in the Network Of Intergovernmental Organizations
}

\author{
Jason Beckfield, Harvard University
}

\begin{abstract}
A growing body of research demonstrates powerful effects of international organizations on national policy, and the literature on international conflict is increasingly adopting a network perspective on international organizations, but we still know little about the network structure of the world polity itself. This is surprising in light of the theoretical implications of world polity theory, world systems theory, and the world civilizations approach to the structure of the world polity. Using data on a set of prominent intergovernmental organizations (IGOs), along with a comparison to the complete population of IGOs, this study examines the world polity as a network structured by symbolic and material conflict. Network analysis reveals a contradictory duality in the structure of the world polity: while states are densely interconnected through international organizations, these international organizations are only sparsely interconnected. Contrary to world polity theory, world system position and world civilization predict position in the world polity. These results show that, in neglecting the network structure of the world polity, previous research has underestimated the extent of structural inequality in the world polity. Because embeddedness in the world polity has such powerful effects on state policies, international trade, and international conflict, the centralization and fragmentation of the world polity may have disintegrative implications for world politics. Keywords: globalization, world polity, world society, regionalization, network analysis.
\end{abstract}

The global network of states and intergovernmental organizations (IGOs), which comprises a central part of the world polity, is shifting the balance of sovereignty among national and global actors, and as such represents a central public concern and social issue (Goldman 2001; Hardt and Negri 2000; Held et al. 1999; Hirst and Thompson 1996; Sassen 1996; Slaughter 2004; Smith 2001; Smith, Solinger, and Topik 1999; Strange 1996). ${ }^{1}$ Over the course of the last century, the population of IGOs grew exponentially, as did states' memberships in those organizations (Boli and Thomas 1997, 1999a). As social scientists grapple with this process of political globalization, many rely on the insights of neoinstitutionalist world polity theory (Barrett and Tsui 1999; Boswell and Chase-Dunn 2000; Boli and Thomas 1997, 1999a, 1999b; Boyle, Songora, and Foss 2001; Guillén 2001; Katzenstein, Keohane and Krasner 1998; Meyer, Boli, Thomas and Ramirez 1997; O’Riain 2000; Thomas and Meyer 1984).

1. The globalization movement has tended to focus on economic rather than political globalization, but it has oriented toward international organizations that promote neoliberal trade policy and thus reflect the intersection of the political and economic dimensions of globalization (Bandy 2004; Fisher et al. 2005; Goldman 2001).

The author thanks the Social Problems editors and reviewers, and Art Alderson, Josef Brüderl, Larry Burmeister, Rob Clark, Hartmut Esser, James Evans, Claudia Geist, Josh Klugman, Beate Kohler-Koch, Peter Kotzian, Ryon Lancaster, Matthew Mahutga, Paulette Lloyd, Patricia McManus, Jocelyn Viterna, and Yang Yang for constructive feedback. Earlier versions of this article were presented at the annual meetings of the Midwestern Sociological Society (St. Louis, 2001) and the American Sociological Association (Atlanta, 2003). This research was supported in part by fellowships from Indiana University. Direct correspondence to: Jason Beckfield, Department of Sociology, Harvard University, 33 Kirkland St., Cambridge, MA 02139. E-mail: jbeckfie@wjh.harvard.edu.

Social Problems, Vol. 55, Issue 3, pp. 419-442, ISSN 0037-7791, electronic ISSN 1533-8533. () 2008 by Society for the Study of Social Problems, Inc. All rights reserved. Please direct all requests for permission to photocopy or reproduce article content through the University of California Press's Rights and Permissions website at www.ucpressjournals.com/reprintinfo/asp. DOI: 10.1525/sp.2008.55.3.419. 
Scholarship from this perspective shows that becoming enmeshed in the world polity-by joining international organizations - is related to policy adoption across diverse domains: education (Schafer 1999; Schofer and Meyer 2005), environmental protection (Frank, Hironaka, and Schofer 2000; Schofer and Hironaka 2005), women's suffrage (Ramirez, Soysal, and Shanahan1997), gender equality (True and Mintrom 2001), same-sex sexual relations (Frank and McEneaney 1999), and human rights (Hafner-Burton and Tsutsui 2005). Indeed, world polity research shows that the effects of the world polity often outweigh the effects of traditional national-level factors.

Recent work also suggests that international organizations-and IGOs in particularmatter for trade (Ingram, Robinson, and Busch 2005), neoliberal restructuring (Henisz, Zelner, and Guillen 2005), international conflict (Boehmer, Gartzke, and Nordstrom 2004; HafnerBurton and Montgomery 2006), and transnational social movement organizations (Smith and Wiest 2005). This newer work, following John Oneal and Bruce Russett (1997), has used the tools of network analysis to understand how dyadic ties among states through their memberships in international organizations influence a range of outcomes. However, this "network turn" has yet to be taken to understand the essential structural properties of the world polity itself. That is, research demonstrates that the network structure matters, but this work has not yet considered the theoretical implications for network structure. Moreover, although research on the effects of world polity ties has begun to disaggregate the IGO field into distinct sets of organizations (Boehmer et al. 2004; Gartzke, Li, and Boehmer 2001; Ingram et al. 2005; Kim and Barnett 2000), work on the structure of the world polity has not gone far in this direction. This article moves further toward disaggregating the world polity by employing two sets of IGOs for the analysis: a set of highly visible IGOs identified by editors of international handbooks, and the complete population of IGOs identified by the Correlates of War project.

In sum, emphasis on the effects and content of the world polity has overshadowed basic research on its structure and shape. Several crucial questions remain unresolved. In the context of exponential growth in the number of international organizations, does the network take the shape of a densely integrated, decentralized, cohesive web, or a sparse, fragmented, centralized network with uneven areas of integration and disconnection? Has the size and inclusiveness of IGOs kept up with the growth in the population of IGOs? Do the new IGOs look more like the universal-membership United Nations (UN), or more like the limitedmembership European Union (EU) and Arab League (AL)? Answers to these questions about the network structure of the world polity matter for four reasons: (1) as the new network research demonstrates, involvement in the world polity affects national policy and international politics; (2) world polity theory, world systems theory, and the world civilizations approach make contradictory claims about the structure of the world polity; (3) the extent of inequality in the world polity may be understated by research that uses simple counts of memberships in international organizations; and (4) actors with privileged positions in the network will be advantaged (Burt 1992; Granovetter 1973; Padgett and Ansell 1993).

In this article, I employ network analysis to take the next step toward understanding the structure of the world polity in 1950 and 2000. These years, 1950 and 2000, provide crucial snapshots, given the formation of the UN system in 1945 and the explosive growth in the population of states and IGOs since then. As John Meyer and colleagues (1997) note: "the development and impact of global sociocultural structuration greatly intensified with the creation of a central world organizational frame at the end of World War II" (p. 163). What sort of a structure did this structuration make? In this article, I develop hypotheses concerning the structure of the network from the world polity, world systems, and world civilizations approaches, and I test these hypotheses using techniques designed for network data. Analyzing the world polity appropriately as a network uncovers substantial—and surprising, in light of some of the claims made by world polity theory—-structural inequality, centralization, and 
fragmentation. Thus, political globalization may carry disintegrative implications for world politics.

To anticipate the results, this disintegration of the world polity is described in two distinct dimensions of the structure of the network. I conceptualize the world polity as a bimodal network, or a network that encompasses two theoretically distinct categories of nodes: IGOs and states. ${ }^{2}$ To grasp the "duality" (Breiger 1974) of this network, it is necessary to analyze two networks: first, the unimodal network of IGOs, where ties represent common member states; and second, the unimodal network of states, where ties represent co-memberships in IGOs. Both networks relate to the theoretical stakes, but in different ways. The IGO network best captures the structural impact of the composition of the IGO field: its regionalization, along with its centralization around a small number of IGOs. That much structural inequality appears on the organizational side of the network suggests that the composition of the field of international organizations-especially the predominance of regional organizations-significantly structures the world polity network as a whole. Examining the IGO network opens up a new set of questions about the interorganizational side of the world polity, and allows for empirical tests of claims about possibilities for diffusion among organizations (Frank et al. 1999; Simmons, Dobbin, and Garrett 2006; Simmons and Elkins 2005). Examining the IGO network also affords a look at the possible organizational sources of connection and disconnection in the world polity, along with the potential for the production and dissemination of complementary or contradictory policy scripts (Frank et al. 1999:99).

In turn, the interstate network comes closest to the dyadic conception of world polity relations employed in research following the network turn, and reveals the density of relations among states in the international system, along with the centralization of the network around the most active states. The unimodal state network also allows for tests of hypotheses that world polity ties are shaped by attributes of states, including world system position and world civilization. It is essential to examine both the presence or absence and the relative strength of network connections in understanding the structure of the world polity, given that the presence or absence of ties reveals the basic architecture of the network, while the strength of ties more sensitively taps the extent of inequality in the network. Again, anticipating the analysis (discussed in greater detail below), I employ both the binary presence/ absence network and the valued strength network to describe fully the network structure of the world polity.

\section{Approaches to the Structure of the World Polity}

\section{World Polity Theory}

World polity theory holds that states embedded in the world polity receive "policy scripts" that prescribe legitimate action (Meyer et al. 1997; Boli and Thomas 1997). IGOs like the UN create, carry, and embody the world culture in the world polity, diffusing policy scripts to states (Meyer 2000; Strang and Meyer 1993), and states adopt common policies as they grow more integrated into international organizations. For instance, states tied more closely to the world polity create agencies promoting gender equality earlier (True and Mintrom 2001), enact pro-environment policies sooner (Frank 1999; Frank et al. 2000), and implement more liberal policies on same-sex sexual relations (Frank and McEneaney 1999). The theory shares with the "third force" approach an optimism toward the ability of the

2. As noted above, the world polity includes other categories of nodes as well, such as international nongovernmental organizations (INGOs), suggesting that the structure of the world polity actually includes more dimensions than those examined in this article. The quality and quantity of relations among all these modes raises a host of important theoretical questions for future work. 
Table 1 - Structural Hypotheses Derived from World Polity Theory, World Systems Theory, and the World Civilizations Approach

\begin{tabular}{llll}
\hline & $\begin{array}{c}\text { World Polity } \\
\text { Level/Change }\end{array}$ & $\begin{array}{c}\text { World System } \\
\text { Level/Change }\end{array}$ & $\begin{array}{c}\text { World Civ. } \\
\text { Level/Change }\end{array}$ \\
\hline $\begin{array}{l}\text { Unimodal network (IGO dyads) } \\
\text { Density } \\
\text { Centralization }\end{array}$ & $\begin{array}{l}\text { high/increase } \\
\text { low/decrease }\end{array}$ & $\begin{array}{l}\text { low/stable } \\
\text { high/stable }\end{array}$ & $\begin{array}{l}\text { low/decrease } \\
\text { low/decrease }\end{array}$ \\
$\begin{array}{l}\text { Unimodal network (state dyads) } \\
\text { Density }\end{array}$ & high/increase & low/stable & low/decrease \\
Wontralization & low/decrease & high/stable & low/decrease \\
horld civilization model fit & low/decrease & low/decrease \\
low/decrease & low/decrease & high/increase \\
\hline
\end{tabular}

world polity to counter traditional geopolitical forces (Bratton 1989; Florini 2000; Rice and Ritchie 1995; Shaw 1991). ${ }^{3}$

Some argue that world polity theory downplays power and inequality (Hall and Taylor 1996:954; Smith 2000:1575; Stinchcombe 1997:17; Thelen 1999:387). Paul DiMaggio and Walter Powell (1983:157) note that the theory does not fully account for power and interests, nor does it attend to questions about who benefits from institutions. Significantly, world polity theory views the structure of the world polity as progressing toward a relatively flat structure, as all states, especially those in poor countries, integrate into the world polity at a faster rate. More specifically, although world polity and "third force" international relations scholars acknowledge inequality in participation in the world polity, and in fact show that variation in embeddedness drives variation in policy outcomes, they downplay this inequality, or argue that while there is structural inequality, it is on the decline (Boli and Thomas 1999a; Florini 2000). In its structure, the world polity is said to be increasingly universal and nonhierarchical: membership in international organizations is "a social imperative" (Boli, Loya and Loftin 1999:56) and "practically compulsory" (p. 76) for states. In earlier work (Beckfield 2003), I show that inequality in the number of memberships in IGOs declined dramatically, and to a very low level, by the year 2000 .

World polity theory implies several hypotheses concerning the basic structure of the network of IGOs and states (these and the other hypotheses developed below are summarized in Table 1). First, if the world polity is "a world of Durkheimian and Simmelian integration" (Meyer et al. 1997:175) and "a rapidly growing web of global links that envelop the world without regard for local topography and conditions" (Boli et al. 1999:77), the network should be densely interconnected, and should become more so over time. Second, if the world polity can be characterized as "stubbornly decentralized" (Boli and Thomas 1997:172), the network should not be centralized around structurally privileged states or IGOs, and any centralization in the network should decline with time. That is, if the world polity is a world where universalist (rather than exclusive) international organizations predominate, the network of states and international organizations would not resemble a "star-shaped" network where a few organizations and states have many more world polity ties than others. Third, neither a state's position in the world system, nor its civilization alignment, should account for its ties to international organizations. That is, world polity theory predicts that dyads of states will become densely interconnected through common ties to international organizations, regardless of how economically, culturally, or geographically similar the dyads are.

3. The "third force" refers to international civil society, as counterpoised to the "first force" of the interstate system and the "second force" of the international market economy. This literature examines the capacity of international civil society (often through INGOs) to counteract the effects of states and markets in the international system. 
In connecting the network concepts of density and centralization to world polity theory (and to the other theories extended below), these concepts require explication. For the purposes of this article, density is used in the network sense, as the proportion of possible ties between dyads that are realized in the observed data. That is, I develop and test hypotheses relating to both the volume and the pattern of world polity ties. This means that while the overall volume of connections within the world polity may suggest an increase in the density of the system as a whole, I argue that the specific pattern of these ties also matters-it matters as much for the world polity that Western European countries have expanded their world polity ties to a very high level as it does that states in other parts of the world have connected to the world polity at a much lower level, if at all. Similarly, on the IGO side of the network, it matters as much for centralization and regionalization that universalist organizations like the UN are tied directly to regional organizations like the EU and to economic organizations like the Organisation for Economic Co-operation and Development (OECD) as it does that regional organizations like the EU and the AL do not share member states. While the impact of density (or sparseness) and centralization (or decentralization) on the content and effects of world polity ties remains an open question, it is an important next step to examine these structural qualities. ${ }^{4}$

Previous research on the structure (versus the effects) of the world polity is limited by its treatment of involvement in the world polity as an attribute of states: involvement in the world polity is measured as the number of memberships in international organizations (including IGOs), but the network itself is not described (Beckfield 2003; Boli et al. 1999; Feld and Jordan 1988; Jacobson 1979; Jacobson, Reisinger, and Mathers 1986; Shanks, Jacobson and Kaplan 1996; Wallace and Singer 1970). ${ }^{5}$ This is a serious oversight, because measuring world political involvement as an attribute of states rather than relations among IGOs and states masks important structural properties of the world polity. For instance, inequality in the number of states' ties to IGOs decreased dramatically since 1960 (Beckfield 2003). However, this may mean little for the structure of the network. It is possible, for instance, that states become more equal in the number of IGO memberships they hold, but that states become less similar in precisely which IGOs they hold memberships in. That is, it could be the case that inequality in states' IGO ties decreases while the network itself becomes less densely interconnected, and states become less similar in the pattern of ties they hold to IGOs. Furthermore, counts of states' IGO memberships say nothing about inequality among IGOs, as the field of IGOs could grow more or less densely interconnected, and more or less centralized, as inequality in the number of states' IGO memberships declines.

Another limitation of previous work on the distribution of world polity ties is that states' ties to every active IGO in a given year are counted in the data set that most studies use (UIA 2000). As has long been recognized by international relations scholars (Singer and Wallace 1970; Gartzke et al. 2001), this blurs important distinctions among organizational fields, lumping disparate organizations together indiscriminately. This also weights membership in, for instance, the World Meteorological Organization the same as membership in, for instance, the EU. ${ }^{6}$ Though this comprehensive count of IGO memberships has been shown to be

4. A significant limitation of this analysis is that it does not examine within-IGO ties. As one can note, large IGOs like the UN entail multiple agencies, each of which may exhibit more or less densely interconnected memberships. Likewise, a full understanding of the structure of the world polity is incomplete without a case-based, process-focused examination of how the structure translates into content and effects.

5. Frank et al. (1999) highlight interorganizational linkages as an aspect of the "rise of the environment in world culture" (p. 81). In this account, the dense connections among environmental IGOs and INGOs are interpreted as evidence "that the environment has become institutionalized in world culture" (p. 90), suggesting one way that the associational structure and the cultural content of world society may relate.

6. The standard UIA data set also includes some questionable classifications of IGOs. For instance, the EU is classified as a "fund" and states' EU memberships are thus excluded from the counts of IGO memberships used in much world polity research (UIA 2000:viii, 876). 
related to state policy, it is possible that states are exposed to different policy scripts within different fields of IGOs, and it is possible that more visible IGOs such as the EU and the UN exert stronger policy effects (cf., Ingram et al. 2005). Below, I compare the complete population of IGOs to a select set of visible IGOs.

I underscore the distinction between hypotheses about the structure of the contemporary world polity versus hypotheses about how the structure of the world polity has changed in the crucial post-World War II era (the hypotheses are summarized in Table 1). While world polity scholars clearly appreciate that some states belong to more international organizations than others (Boli et al. 1999), they emphasize that this inequality is declining (Beckfield 2003; Boli et al. 1999). That is, although a high level of structural inequality in the world polity is not inconsistent with the expectations of world polity theory, and thus not adjudicative of the competing hypotheses, world polity theory does imply that structural inequality should be on the decline, as states form and join global IGOs like the UN. Thus, although a static analysis of the contemporary network structure of the world polity represents a significant advance over current literature, adding an earlier time point to the analysis as a baseline for comparison allows for a more stringent test of the relevant hypotheses.

\section{World System in the World Polity}

Characterization of the world polity as flat contrasts with the vision of the world system as a hierarchical network of nation-states bound by competitive, unequal relations (ChaseDunn and Grimes 1995; Boswell and Chase-Dunn 2000). World systems theory characterizes international organizations as "sites of conflict and power" (Boswell and Chase-Dunn 2000:199), in the same way that the international trade network reflects global inequality. From this perspective, the world polity develops within the world order, or "the agreed upon and normative rules of international relations" (p. 24). Because world orders are established by core hegemons and benefit the international capitalist class, world political organizations become "boards of directors for ruling states" (p. 238). In this radical conception of the world polity, core states use international organizations to establish and enforce an international order designed to their benefit. Structurally, this implies a dominance of the core over the world polity, with a more limited participation of peripheral states in those organizations that are captured by the core.

While the world systems approach suggests that the number of world polity ties may be an important resource, it is position in the world polity-the patterning of ties to particular states and organizations-rather than the volume of ties on its own that matters. If the world systems account is correct, position in the world system is likely to be especially relevant to position in the world polity, since the core has a material interest in maintaining the global capitalist order through the creation and diffusion of policy scripts. Following the "conflict model" of the world polity (Beckfield 2003), core states can dominate the world polity in multiple ways: by dominating the membership of existing IGOs, or by forming new IGOs, or by restricting membership to IGOs. This argument implies that the world political network should become increasingly dominated by core states, and contradicts the argument that noncore states form IGOs to counter the neoliberal economic order (Krasner 1985). World systems theory also suggests that core powers are especially likely to dominate more visible IGOs; this is examined below in the comparison of the visible-IGO subset and the complete population of IGOs.

In the language of world systems theory, the "core-periphery hierarchy" is a "structural constant" that is "continually reproduced," and "further, while the scale of the system increases as it expands, the structures have gotten larger without fundamentally changing" (Boswell and Chase-Dunn 2000:20). These ideas can be extended to suggest several structural hypotheses in the context of exponential growth in the population of and participation 
in IGOs. First, the world polity should be sparsely interconnected, and the density of the network should remain stable over time, as the core continues its dominance of international organizations. Second, the world polity should be highly centralized around structurally privileged states and IGOs, and should remain stably centralized, or even grow more centralized, over time. ${ }^{7}$ Third, a world system model network where the core is tied to itself, the semiperiphery, and the periphery, but noncore states are not interconnected should explain the pattern of world polity ties (and thus should help to account for stable centralization and sparseness in the network).

\section{Culture and Geography in the World Polity}

Samuel Huntington (1996) provocatively claims that the major geopolitical fault lines are no longer economic or ideological (viz., capitalist versus communist), but are instead cultural: "global politics is being reconfigured along cultural lines. Peoples and countries with similar cultures are coming together. Peoples and countries with different cultures are coming apart" (p. 125). Huntington argues that the world divides into roughly nine "civilizations"Western, Latin American, African, Islamic, Sinic (Chinese), Hindu, Orthodox, Buddhist, and Japanese-with distinct value systems (Inglehart and Baker 2000). According to Huntington, the Western/non-Western cleavage is central, but the many non-Western civilizations also differ, and there are important conflicts between them. These cultural distinctions are likely to be especially relevant to the structure of the world polity, because the world polity constructs and reflects world culture.

The world civilizations approach suggests structural hypotheses. First, if the world is growing increasingly divided along cultural lines, the world polity should be sparsely interconnected, and the density of the network should decrease over time, as states form and join IGOs based on cultural affiliation. That is, while the density of the network within civilizations will increase, the overall density of the network will decrease much more quickly, as civilization alignment drives states toward one civilization and away from eight. Second, if cultural conflict produces a world polity that is fragmented and multipolar, then the world polity should exhibit a low level of centralization, and this centralization should decrease with time. Third, states from common civilizations should belong to the same IGOs, resulting in a network where states that share civilizations are closely interconnected, while states aligned with different civilizations are disconnected.

It is important to note that civilizational alignment corresponds closely with geographic region, so that a growing structuration of the network of IGOs and states by civilization would also reflect a growing regionalization of the world polity (Fligstein and Merand 2002, Katzenstein 2005; Kim and Shin 2002), where regionalization can be conceptualized as "the intensification of international interaction within bounded regions" (Beckfield 2006:966). This regionalization, which involves the construction of "social arenas where people and organizations come to routinely interact" (Fligstein 2007:11) driven in part by regional polities like the EU, the Mercado Común del Cono Sur (Mercosur), and the North American Free Trade Agreement, might produce a fragmented world polity. Of course, it is possible that regionalization and globalization are complementary or contradictory in their effects, so I reiterate here that the analysis below speaks only to the associational structure (and not the content) of world polity ties. If the structure of the world polity does correspond to civilization/region, more work will be needed to disentangle the causes of this associational structure.

7. The key distinction between the predictions of world polity theory and world systems theory for changing centralization is that between decreasing centralization and another pattern, as either stable centralization or increasing centralization could reflect the consolidation of core interests in the world polity. Future work should also explore how changes in the structure of capitalist accumulation relate to changes in the structure and effects of the world polity. 


\section{Network Data and Analysis}

The goal of this article is to use the techniques of network analysis (Wasserman and Faust 1994) to describe the structure of the world polity. Specifically, I examine the properties of density, centralization, and fitness to ideal-typical model networks to assess how well the various images of the world polity drawn from the literature characterize the actual worldpolitical network. Below, I describe the network data, and detail how I calculate the network properties of density, centralization, and fitness to models.

Network analysis requires relational rather than attributional data. Whereas the typical data structure used in linear regression analysis is the rectangular case-by-variable matrix, where cell $x_{\mathrm{ij}}$ represents an observation on variable $j$ for case $i$, the classical network analysis data structure is the square case-by-case matrix, where cell $x_{\mathrm{ij}}$ represents a tie between nodes $i$ and $j$ on a given relation. For this network analysis of the world polity, the data form a bimodal network with two distinct sets of nodes: states and IGOs (on bimodal networks, see Breiger [1974] and Galaskiewicz [1985]). The 1950 network of prominent IGOs, discussed in more detail below, can be thought of as an $11 \times 102$ ( 11 IGOs and 102 states) binary matrix where an entry in cell $x_{\mathrm{ij}}$ indicates membership of state $j$ in IGO $i$. The 2000 data matrix is also bimodal, with the 50 rows representing 50 IGOs and the 206 columns representing the 206 states. Network analysis of bimodal data typically focuses on unimodal co-membership and overlap networks implicit in the bimodal network. In the network of states and IGOs, the bimodal network can be used to generate a state-by-state square, valued co-membership matrix where cell $x_{\mathrm{ij}}$ gives the number of IGOs that states $i$ and $j$ hold common membership in. Likewise, an IGO-by-IGO square, valued overlap matrix can also be generated, where cell $x_{\mathrm{ij}}$ indicates the number of states that are members of both IGO $i$ and $j$.

I use two sets of IGOs for the analysis: a list of prominent IGOs as compiled by editors of international handbooks, and a list of the complete population of IGOs identified by the Correlates of War project. The list of prominent IGOs comes from two sources: The Statesman's Yearbook (Steinberg 1950; Turner 2000) and The Europa Yearbook (Europa Publications 1961, 2000). The Statesman's Yearbook has been published since 1863; The Europa Yearbook, since 1926. Both are often used as a data source in comparative and international relations research (e.g., Meyer et al. 1997; Moon 2003; Oneal and Russett 2001). For the analysis, an IGO and its members were included in the data if the IGO appeared in either source. Tables 2 and 3 list the IGOs included in the first data set. ${ }^{8}$

I also use data on the complete population of IGOs, as assembled and distributed by John Pevehouse, Timothy Nordstrom, and Kevin Warnke (2004) as part of the Correlates of War project. Pevehouse and associates (2004:103) note that "the broadest understanding of what constitutes an IGO is that the organization (1) is a formal entity, (2) has states as members, and (3) possesses a permanent secretariat or other indication of institutionalization such as headquarters and/or permanent staff." The 1950 network includes 119 IGOs and 82 states; the 2000 network, 330 IGOs and 190 states. These data are commonly employed by international relations scholars who study interstate dyads (Boehmer et al. 2004; Oneal and Russett 1997; Russett, Oneal and Davis 1998). For both the list of prominent IGOs and the population of IGOs identified by Pevehouse and associates (2004), the raw data are simply IGO membership lists, which are transformed by the UCINET network analysis software package

8. I replicated the density and centralization analyses for 1950 and 1992 (the latest year available), using Gartzke's data on interstate ties through maximally-institutionalized IGOs (Boehmer et al. 2004). For the valued interstate network, density increases from 6.982 to 13.227 , while centralization decreases slightly from .127 to .114. Examining ties through minimally-institutionalized IGOs, again using the valued network, density increases from 1.256 to 4.357, while centralization decreases from .174 to .100. That these results are consistent with those shown below (see Tables 4 and 5 ) suggests that the results are not driven by the method used to select the sample of IGOs. 
Table 2 • Prominent Intergovernmental Organizations, 1950

\author{
Arab League \\ British Commonwealth and Empire \\ Brussels Treaty Organization \\ Caribbean Commission \\ Commission for Economic Cooperation \\ Council of Europe \\ North Atlantic Treaty Organization \\ Organization for European Economic Cooperation \\ Organization of American States \\ South Pacific Commission \\ United Nations
}

Sources: The Statesman's Yearbook (Steinberg 1950) and The Europa Year Book (Europa Publicaitons 1961)

(Borgatti, Everett and Freeman 2002) into the bimodal matrices. From these bimodal networks, unimodal networks are generated.

Appendix A shows illustrative extracts of the data matrices (from the subsample of prominent IGOs). In the first matrix, a 1 indicates the membership of a state in an IGO. Algeria is a member of the $\mathrm{AL}$, Brazil is a member of the Common Market of the Southern Cone, and all the states shown in this small extract of the data are members of the UN. The second matrix shows the ties among organizations that are formed by common member states. For instance, the EU shares no members in common with the AL or OPEC, but shares 11 members in common with NATO, and all 15 members of the EU are also members of the UN. The diagonal of this matrix shows the number of states that belong to each organization: the AL has 22 members, the Common Market of the Southern Cone, or Mercosur, has 4 members, and so on. The third matrix shows how strongly states are connected through common memberships in IGOs. For instance, the United States and Germany are very tightly connected, with 9 IGOs in common, whereas the United States is more distant from Algeria, with only 2 IGOs in common. The diagonal shows the total number of IGOs each state holds memberships in: Germany and the United States are both very active, with 14 IGO ties each.

Before turning to the details of the analysis, the implications of the changing population of IGOs should be explicitly considered. It is apparent from a comparison of Tables 2 and 3 that there are far more regional IGOs in 2000 than there were in 1950, and more heterogeneity in the IGO field more generally. Indeed, the reader might ask whether this changing population of IGOs predetermines the results of the analysis. The reader might also ask whether regional IGOs should be excluded from the analysis, since it is difficult to consider every state a viable candidate for membership in every regional IGO. In response, I argue that the appearance of so many regional IGOs itself carries important theoretical implications, and relates to general ontological debates within the globalization literature (Fligstein 2001; Guillén 2001). Clearly, the IGO population need not have seen the appearance of so many regional IGOs, and indeed there is no reason why universalist IGOs could not have flourished at an equal or greater rate. This counterfactual is a theoretically meaningful and practically plausible baseline for comparison. Moreover, regions and regional boundaries are socially constructed and negotiated political projects (Katzenstein 2005). Turkey's current candidacy for membership in the EU is a notable case of this. Finally, the presence of regional organizations could be consistent with a dense or sparse, centralized or decentralized network.

Although it is important to bear in mind both the substantive and methodological importance of regional organizations, I also conducted a supplemental analysis holding the sample of IGOs constant across the two time points. The ten IGOs in this subsample are the IGOs shown in Table 2, less the Commission for Economic Cooperation, a Soviet-era organization 
Table 3 - Prominent Intergovernmental Organizations, 2000

African Development Bank

Andean Community

Antarctic Treaty

Arab Maghreb Union

Asian Development Bank

Asia-Pacific Economic Cooperation

Association of Caribbean States

Association of Southeast Asian Nations

Black Sea Economic Cooperation Group

Caribbean Community*

Central American Integration System

Central European Initiative

Colombo Plan

Common Market for Eastern and Southern Africa

Commonwealth, formerly British Commonwealth and Empire*

Commonwealth of Independent States

Co-Operation Council for the Arab States of the Gulf

Council of Baltic Sea States

Council of Europe*

Danube Commission

Economic Community of West African States

Economic Cooperation Organization

European Free Trade Association

European Space Agency

European Union

Franc Zone

Francophonie Institutionnelle

Inter-American Development Bank

International Organization for Migration

Lake Chad Basin Commission

Latin American Integration Association

League of Arab States, formerly Arab League*

Nordic Council

North American Free Trade Agreement

North Atlantic Treaty Organization*

Organization for Economic Cooperation and Development, formerly OEEC*

Organization for Petroleum Exporting Countries

Organization for Security and Cooperation in Europe

Organization of African Unity

Organization of American States*

Organization of Arab Petroleum Exporting Countries

Organization of Eastern Caribbean States

Organization of the Islamic Conference

Pacific Community, formerly South Pacific Commission*

South Asian Association for Regional Cooperation

South Pacific Forum

Southern African Development Community

Southern Common Market

United Nations*

Western European Union, formerly Brussels Treaty Organization*

Sources: Statesman's Yearbook (Turner 2000) and Europa Year Book (Europa Publications 2000)

*Indicates an IGO that was present in 1950 
whose members were Albania, Bulgaria, Czechoslovakia, the German Democratic Republic, Hungary, Poland, Romania, and the USSR. To anticipate the results, which are discussed in the text below, this supplemental analysis of a constant subsample of IGOs is consistent with the results shown in the tables for the prominent IGOs and the complete population of IGOs. This suggests that the results are not simply a function of the changing population of IGOs, but also reflect significant changes in the structure of states' involvement with world polity organizations.

Conceptualizing and analyzing the world polity as two distinct networks-one of IGOs and one of states-provides critical leverage on the question of how the structure of the world polity is evolving. The networks of IGOs and states reveal different aspects of the structure of the world polity. The IGO network can be used to assess the universality of IGOs in their membership. Analysis of this network can show whether the world polity is better characterized as a dense web of IGOs that share many members in common, or a sparser web where IGOs do not share many members. It is also possible to determine whether the increasing participation of states in IGOs produces a more densely interwoven world polity, or the increasing involvement of states in IGOs is offset by the creation of new IGOs. The unimodal network of states also helps reveal structural characteristics of the world polity. The interstate network shows the pattern of connections between states formed by their IGO memberships. Analysis of this network can show how densely states are tied together, and whether the interstate network is best characterized as a flat structure where all states are tied to each other fairly evenly, or an unequal structure where some states are knitted closely together through common IGO memberships while others remain isolated at the periphery of the world polity.

For both the inter-IGO and the inter-state network, I calculate measures for the binary network, where ties are simply present $(=1)$ or absent $(=0)$, and for the valued network, where ties are counts of connections. I examine both the binary and valued networks because each reveals distinct aspects of the network structure. The binary network more closely approximates the basic architecture of the world polity, including points of connection and disconnection. Most importantly, the binary network more accurately represents the overall pattern of ties, while analysis of the valued network can be swamped by a few active nodes. For instance, density would be biased upward by a highly-skewed degree distribution, in the same way that "average income" is affected by a skewed income distribution. Density and centralization, discussed in detail below, are also more easily interpreted when calculated for binary networks, since both range from 0 to 1 for binary networks (the theoretical range is undefined for valued networks). Analysis of the valued networks, on the other hand, shows how strongly states and organizations are intertwined, which is significant given that research on the effects of world polity ties typically employs a count of memberships in international organizations.

\section{Density}

The fundamental structural claims of world polity theory concern the density of the network: the world polity is argued to be a densely interconnected network with close ties among organizations and states. Density is one of the most basic properties of a network: it is the proportion of potential ties within a network that are actually observed. Because "potential ties" include ties from states outside regions with regional organizations, the density of the bimodal network is relevant to an assessment of the regionalization of the world polity. For unimodal, symmetric networks without self-ties, density is:

$$
\mathrm{D}=\operatorname{tg}(g-1) \text {, }
$$

where $t$ is the total number of ties in the network, and $g$ is the number of nodes in the network (Wasserman and Faust 1994:102). 
Density is calculated for both sets of IGOs, and, within each set, for both networks: the network of IGOs and the network of states. The density of the network of IGOs reveals what proportion of IGO dyads share a member state in common, while the density of the network of states reveals what proportion of state dyads share membership in a common IGO. The range of density for a binary network is 0 to 1 , and density in such networks is interpreted as the proportion of possible ties that are realized. For valued networks, the theoretical range is undefined; density in valued networks is the average strength of a tie. I note that "density" is employed here in strictly network-analytic terms, as defined above. While Tables 2 and 3 show that the opportunities for world polity ties have grown enormously, it is an open empirical question whether this increase, or potential future increases, result in a world polity that is more or less densely knit together by memberships of states in international organizations.

\section{Centralization}

I measure structural inequality in the networks as centralization. Centralization is a network-level index that varies from 0 to 1 and captures the extent to which the network has one central node and many peripheral nodes (Wasserman and Faust 1994). As such, it taps a strict variety of hierarchy. Specifically, I analyze degree centralization, which quantifies the extent to which the network has one central node with ties to all other actors, but no ties between the other actors (Freeman 1979). The formula is:

$$
\mathrm{C}_{\mathrm{D}}=\Sigma\left[C_{D}\left(n^{*}\right)-C_{D}\left(n_{\mathrm{i}}\right)\right] /[(g-1)(g-2)],
$$

where $C_{D}\left(n^{*}\right)$ is the degree centrality of the most central node, $C_{D}\left(n_{\mathrm{i}}\right)$ is the degree centrality of node $i$, and $g$ is the number of nodes in the network (Wasserman and Faust 1994:180). In binary networks, the centralization index ranges from 0 to 1 . In a decentralized network where every node has a tie to all other nodes, or where all nodes have the same number of ties, the centralization index would equal 0. Conversely, a centralization index of 1 would be observed for a perfectly centralized, star-shaped network with one central node. While centralization and density are related (in that a maximally-dense network is minimally centralized), they describe conceptually distinct aspects of network structure. A dense network can be relatively centralized (star-shaped) or decentralized, as can a sparse network (Wasserman and Faust 1994). ${ }^{9}$

\section{Fit of Model Networks to Observed Networks}

Density and centralization are descriptive characteristics. As such, they can be used to test the claims made by the various approaches about the basic structure of the world polity, but they have limited utility for assessing the correspondence of the observed structure to a model. Both the world systems and world civilizations approaches imply specific models of world polity structure. The world systems approach to the world polity implies that core states should be tied to core, semiperipheral, and peripheral states, while semiperipheral and peripheral states should be tied only to core states. ${ }^{10}$ The world civilizations approach implies

9. This is related to the connection between inequality in the number of ties and structural inequality in a network: states can exhibit similar levels of IGO ties, but if states are systematically tied to different IGOs, there may still remain significant structural inequality.

10. This model represents the world system as a core-periphery structure, and as such treats semiperipheral states as equivalent to peripheral states with respect to the world polity. While alternative models are possible, the model used here allows for a conservative test. Data on world system position come from Bollen's (1983) and Bollen and Appold's (1993) updates of Snyder and Kick (1979), supplemented with information from Kentor (2000) and World Bank (2002) for states not included in the original sources. 
that Western states should be tied to other Western states; Islamic states should be tied to other Islamic states, and so on. ${ }^{11}$

To evaluate these competing explanations of the pattern of world polity ties, I construct idealized world system and world civilization networks and compare them to the observed world polity data. These networks are represented as square, binary, symmetric matrices (Appendix B shows small extracts for illustration). To compare model to data, I estimate Pearson correlations (range: - 1 to 1 ) between these hypothetical networks and the observed data. Because the observations are not independent, statistical significance cannot be assessed in the standard way, so I instead employ the nonparametric quadratic assignment procedure (QAP). As implemented in UCINET, QAP randomly permutes the observed data matrix 5,000 times, calculating a correlation between each permuted data matrix and the model matrix. Statistical significance is indicated by the proportion of random permutations that produce a correlation as large as that observed between the data and model matrices. See Kadushin (1995), Mizruchi (1990), and Padgett and Ansell (1993) for applications of the QAP method.

\section{Results}

\section{Density}

The hypotheses concerning density of the world political network are clear. World polity theory holds that the world polity is densely interconnected, and should become more so over time. In contrast, world systems theory predicts a sparse network that changes little over time, and the world civilizations approach suggests a sparse network that becomes even sparser over time as civilization- and region-based IGOs fragment the world polity. Table 4 shows results from the density analysis.

Analysis of density in the unimodal IGO and interstate networks reveals the dual structure of the world polity. On the IGO side of the network, the memberships of IGOs overlap less in 2000 than in 1950. In 1950, 64 percent of prominent IGO dyads (and 79 percent of all IGO dyads) shared at least one state as a member. By 2000, only 40 percent of prominent IGO dyads (and 53 percent of all IGO dyads) had at least one common member state. These results also hold for the subsample of ten prominent IGOs present in both 1950 and 2000: in this network, 76 percent of IGOs shared at least one member state in common in 1950, but this declined to 67 percent by 2000. This suggests that IGOs are becoming less universal in their membership, which is more consistent with the world systems and world civilization approaches to the world polity. The analysis of the valued inter-IGO network shows that the IGOs that are tied together are tied together slightly more closely in 2000 than in 1950 (up from 3.18 to 3.37 for prominent IGOs, up from 6.51 to 6.83 for all IGOs, and up from 3.82 to 8.78 for the time-invariant sample of ten IGOs). This difference between the decreasing density of the binary network and the increasing density of the valued network suggests that the topology of the world polity is growing more uneven, fragmented, and marked by areas of tight interconnection and zones of disconnection.

World polity theory better accounts for the structure of the state co-membership network than for the structure of the IGO network. In interpreting the results for the interstate network, I note that only one IGO would be necessary to produce a binary state-by-state network with density equal to 1 , if every state were a member of that IGO. The results show that in the sample of prominent IGOs, fewer than half of state dyads had a common IGO membership 
Table 4 - Density of the World Polity, 1950 and 2000

\begin{tabular}{lrr}
\hline Sample of prominent IGOs & \multicolumn{1}{c}{1950} & \multicolumn{1}{c}{2000} \\
\hline IGO dyads-binary & .636 & .403 \\
IGO dyads-valued & 3.182 & 3.372 \\
State dyads-binary & .492 & .856 \\
State dyads-valued & .584 & 1.755 \\
Population of IGOs & & \\
IGO dyads-binary & .790 & .528 \\
IGO dyads-valued & 6.505 & 6.828 \\
State dyads-binary & .903 & .999 \\
State dyads-valued & 12.721 & 28.953 \\
\hline
\end{tabular}

Notes: The sample of prominent IGOs includes 11 IGOs and 102 states in 1950; in 2000, it includes 50 IGOs and 206 states. The population of IGOs includes 119 IGOs and 82 states in 1950; in 2000, it includes 330 IGOs and 190 states.

in 1950 , but this increased sharply to 86 percent in $2000 .^{12}$ In the population of IGOs, the interstate network is also very dense, increasing from .90 in 1950 to just shy of 1.0 in 2000. There is a similar increase in density in the interstate network created by the subsample of ten IGOs: density changes from .49 to .83. Interestingly, the analysis of the valued interstate network shows that the average strength of interstate ties also increased dramatically, supporting world polity theory. In 1950, states shared an average of .58 prominent IGO ties, and this increased to 1.76 by 2000 . Including all IGOs, average interstate ties grew from 12.72 to 28.95. Including just the prominent IGOs that existed both in 1950 and 2000, average interstate ties grew from .58 to 1.0. Overall, the density results are consistent with a scenario where states rapidly increase their ties to IGOs, while the IGOs states connect to become much less universalist in their membership profiles. Again, the density results suggest that although opportunities for world polity ties grew enormously over the period as both the population of IGOs and the population of states grew in number, the actual membership profiles of IGOs did not change in a way that produced a more densely interconnected network of IGOs.

\section{Centralization}

World polity theory suggests that the world polity should be decentralized, and become even less centralized over time, while world systems theory suggests a stably (or even increasingly) centralized network, and the world civilizations approach suggests a low and decreasing level of centralization. Table 5 shows the results for both sets of IGOs, and both the binary and valued networks of IGOs and states. Note that the binary transformation of the unimodal IGOs overlap and state co-membership matrices biases downward the centralization of both networks as information on the level of overlap and co-membership between dyads is lost. For instance, in the unimodal, binary IGO network, $x_{\mathrm{ij}}=1$ means that IGOs $i$ and $j$ share at least one member state. However, what is lost in the sensitivity of the measurement of ties is gained in interpretability of the centralization index, since the theoretical range of 0 to 1 applies only to the binary network. Thus, although I emphasize the binary-network results, because the interpretation is clearer, I also discuss the valued-network results.

12. However, results from bootstrap $z$-tests suggest that the density of the unimodal state co-membership network is significantly different from 1.0, the density of a model world polity network where all states are interconnected through IGOs ( $z=-5.04$; see Snijders and Borgatti [1999] for a discussion of the bootstrap procedure). 
Table 5 - Centralization in the World Polity, 1950 and 2000

\begin{tabular}{lrr}
\hline Sample of prominent IGOs & 1950 & \multicolumn{1}{c}{2000} \\
\hline IGO dyads-binary & .444 & .622 \\
IGO dyads-valued & 6.378 & 18.532 \\
State dyads-binary & .458 & .131 \\
State dyads-valued & .878 & 1.789 \\
Population of IGOs & & .475 \\
IGO dyads-binary & .213 & 26.680 \\
IGO dyads-valued & 13.330 & .001 \\
State dyads-binary & .062 & 12.978 \\
State dyads-valued & 10.840 &
\end{tabular}

Notes: The sample of prominent IGOs includes 11 IGOs and 102 states in 1950; in 2000, it includes 50 IGOs and 206 states. The population of IGOs include 119 IGOs and 82 states in 1950; in 2000, it includes 330 IGOs and 190 states.

The binary networks of IGOs are highly centralized in 2000, with the network of prominent IGOs 62 percent as centralized as possible, the network of all IGOs 48 percent as centralized as possible, and the subsample of ten IGOs 42 percent as centralized as possible. In structural terms, the inter-IGO network fairly closely resembles a star, with central IGOs tied to many other IGOs through their member states, and a peripheral set of IGOs connected only to the center and not to each other. This centralization was an increase over the levels of 44 percent, 21 percent, and 31 percent, respectively, observed for the three networks in 1950. Centralization also increases in the valued IGO networks: from 6.38 to 18.53 for prominent IGOs, from 13.33 to 26.68 for the population of IGOs, and from 6.47 to 20.69 for the constant-IGOs subsample. Both the relatively high level of and the direction of change in centralization are at odds with the hypotheses drawn from world polity theory. These findings are also inconsistent with the hypothesis of stable centralization drawn from world systems theory, and the hypothesis of decreasing centralization taken from the world civilizations approach.

In contrast to the network of IGOs, the interstate network has become notably less centralized since 1950, consistent with world polity theory. In all three sets of IGOs, the interstate network was fairly centralized in 1950, but this centralization decreased dramatically between 1950 and 2000 (from .46 to .13 for prominent IGOs, from .062 to .001 for the population of IGOs, and from .46 to .14 for the ten constant-case IGOs), with states becoming much more evenly tied to each other. Interestingly, the results for centralization using the valued networks are more ambiguous: centralization increases for prominent IGOs from .88 to 1.79 , and for the complete population of IGOs from 10.84 to 12.98 , but decreases slightly for the constant-IGOs subsample from .88 to .75 . Taken together, this suggests some evidence that there is more structural inequality even in the interstate network, if variation on the strength of ties is incorporated into the analysis. Still, the finding of a low level of centralization in the binary interstate network is generally consistent with the world civilizations approach, and it contradicts the prediction of stable, high centralization drawn from world systems theory.

Apart from the network-level centralization indices, it is also informative that the most central IGOs and states in the world polity networks are those that would be anticipated by a conflict-centered approach to the world polity (Beckfield 2003). The UN, three large international development banks, International Organization for Migration, and Organization for Security and Cooperation in Europe are the most central IGOs, and the most central states are all in the core: France, Canada, Belgium, the United States, Italy, the United Kingdom, 
Table 6 - Fit of the Model World System Network to the World Polity, 1950 and 2000

\begin{tabular}{lll}
\hline Sample of prominent IGOs & 1950 & 2000 \\
\hline State dyads-binary & $.088^{*}$ & $.069^{*}$ \\
State dyads—valued & $.135^{*}$ & $.174^{*}$ \\
Population of IGOs & & \\
State dyads—binary & .107 & .005 \\
State dyads—valued & $.387^{*}$ & $.127^{*}$ \\
\hline
\end{tabular}

Notes: ${ }^{*} p<.05$, based on QAP correlation implemented in UCINET 6, with 5,000 permutations (Borgatti et al. 2002); see text for details. The sample of prominent IGOs includes 11 IGOs and 102 states in 1950; in 2000, it includes 50 IGOs and 206 states. The population of IGOs includes 119 IGOs and 82 states in 1950; in 2000, it includes 330 IGOs and 190 states.

and Germany. Informal scrutiny of the centralization results thus suggests that core states and economic interests are at the center of the world polity.

\section{World Polity, World System, and World Civilizations}

World systems theory holds that the world polity is structured by the world system: knowing which states are core, peripheral, and semiperipheral should explain which states share ties to IGOs. Extending the world systems approach to the network analytic framework suggests the hypothesis that core states share IGO memberships with semiperipheral and peripheral states, but that semiperipheral and peripheral states do not share IGO memberships among themselves. That is, the only IGOs that weaker states belong to are those that are dominated by the core (see Appendix B). Table 6 shows results from QAP correlation analysis of the association between this model world system network and the observed unimodal state co-membership networks. Results are shown for both sets of IGOs, and for both the binary and valued networks, since these networks reveal distinct dimensions of the structure of the world polity.

In the valued networks, the world system model predicts world polity ties in both 1950 and 2000, for both sets of IGOs. Core-core, core-semiperipheral, and core-peripheral dyads are have significantly more shared IGO memberships than semiperipheral or peripheral dyads. For prominent IGOs, the size of the correlation increases slightly (to a still-low level of .17) over time, while for the complete population of IGOs, it decreases from .39 to .13. ${ }^{13}$ This may suggest that core dominance of IGOs is growing more pronounced in more visible, and potentially more influential, IGOs, although more research is needed to test this hypothesis directly. These findings for the world systems model suggest that the world system structures the world polity. Specifically, the world polity is one where the core dominates the semiperiphery and periphery by including them in IGOs, while semiperipheral and peripheral states tend to fail to form and join IGOs.

The world civilizations approach to world politics holds that world political conflict is increasingly structured by culture. It is alleged that states aligned with different "civilizations" are breaking apart, while states that share civilizations are banding closer together.

13. Because the model networks are binary, these Pearson correlation coefficients may be biased downward. Simple matching coefficients (available from the author) for QAP analyses using the binary networks are much larger, but the direction of change in the coefficients for the 1950-2000 comparison is identical to that shown in the tables. 
Table 7 - Fit of the Model World Civilization Network to the World Polity, 1950 and 2000

\begin{tabular}{lll}
\hline Sample of prominent IGOs & 1950 & 2000 \\
\hline State dyads-binary & $.180^{*}$ & .002 \\
State dyads-valued & $.343^{*}$ & $.312^{*}$ \\
Population of IGOs & & \\
State dyads-binary & .057 & .010 \\
State dyads-valued & $.440^{*}$ & $.325^{*}$ \\
\hline
\end{tabular}

Notes: ${ }^{*} p<.05$, based on QAP correlation implemented in UCINET 6, with 5,000 permutations (Borgatti et al. 2002); see text for details. The sample of prominent IGOs includes 11 IGOs and 102 states in 1950; in 2000, it includes 50 IGOs and 206 states. The population of IGOs includes 119 IGOs and 82 states in 1950; in 2000, it includes 330 IGOs and 190 states.

Extending this approach to the network analytic framework suggests the hypothesis that states' memberships in IGOs should be associated with world civilization: those states that share civilization should also share IGO ties (see Appendix B). This hypothesis can be tested using QAP correlation analysis. Table 7 shows these associations between the observed network of world polity ties and the model network drawn from the "clash of civilizations" approach.

The world civilization model predicts IGO ties in the binary world polity network in 1950, but not in 2000 (neither correlation is significant for the full set of IGOs). The correlation between belonging to the same world civilization and sharing an IGO membership has disappeared. If it only matters whether states do or do not share at least one common IGO membership, then we can say that states join IGOs without regard to world civilization: in this binary image, the world polity has disconnected from world civilization since 1950.

This is not the case if we allow for a valued world political network, one where not just the presence or absence but the number of ties, i.e., the strength of bonds-is important. The valued interstate co-membership matrix correlates significantly with the world civilization model in 1950 and 2000, though the correlation in 2000 is slightly smaller. For prominent IGOs, the correlation shrinks from .34 to .31; for the full set of IGOs, the correlation shrinks from .44 to .33 . This indicates that alignment with a common civilization strengthens IGO ties between states, but that the effect of this alignment has weakened slightly with time. Together with the findings from the binary network, we see that by the year 2000 states may be connected to or disconnected from each other regardless of civilization, but that civilizational alignment does increase the strength of these connections. Again, because "civilization" is so closely associated with geographic region, these results can also be interpreted as evidence for a significant regionalization of the world polity. This association between world civilization and world polity ties is stronger than that between world system and world polity.

In sum, the results from Tables 6 and 7 provide some support to all three perspectives on the world polity. World systems theory is supported by the finding that the structure of the world system is reproduced in the structure of the world polity. Likewise, the world polity is also structured by world civilization and world region, which supports the world civilization and regionalization approaches. Yet, significantly, world polity receives support from results showing that the associations between world system and world polity, and world civilization and world polity, have declined in the more than 50 years since the establishment of the UN system. 


\section{Discussion}

This article contributes to the growing literature on political globalization and the world polity by revealing the network structure of IGOs. Though previous research on the world polity conceptualizes it as a network, the world polity has not been analyzed appropriately as a network (although the large effects of world polity network ties have been demonstrated). Thus, there is a lack of fundamental research on the international organizations that increasingly shape national policy and play a significant role in political globalization. This article develops and tests hypotheses drawn from world polity, world systems, and world civilizations approaches concerning various formal network properties of the world polity, including density and centralization. While the network of states has become more densely interconnected and less centralized, the network of IGOs that ties states together has itself become less densely interconnected and more centralized. Also, model networks drawn from world systems theory and the world civilizations approach are significantly associated with world polity ties, suggesting that world polity ties are spread unevenly, and reproduce material inequality and cultural/geographic divides. Thus, a key contribution of this article is to highlight some of the factors that shape the world polity ties that seem to be so influential for a range of political and economic outcomes. One of these factors is place: civilization, strongly related to geographic region, structures world polity ties, which suggests that the "world" polity may also be a world of densely integrated regional polities (Katzenstein 2005). The IGOs of Western Europe, including the influential EU, are the best examples of this regionalization (Beckfield 2006; Fligstein 2007).

Findings from formal network analysis of the world polity hold several additional theoretical implications. Though density is a simple property of networks, it is also a revealing one. The finding that the network of IGOs is sparse and has become even less dense over time implies that prominent IGOs tend to be exclusive rather than universal in membership. Many IGOs are explicitly regional in character (e.g. the North American Free Trade Agreement, and the EU). As place is not innocent of power, the understanding of the world polity drawn from world systems theory comes closest to accounting for this aspect of network structure. Still, the structure of the world polity is more complex than world systems theory allows: the correlation between an idealized world system network and the world polity is statistically significant but small. Also, world polity theory clearly has a large part of the story correct when it comes to network density: very few states share no IGO memberships, and the percentage of these null dyads in the network shrank to a very low level in 2000. This raises an important question for future work: are state dyads that share no IGO memberships more different from dyads that share one or more memberships, or are dyads that share fewer IGO memberships more different from dyads that share more memberships? Another way of asking the question is: does world political conformity depend on the depth of embeddedness into the world polity?

The world systems account of the world polity also receives some support from the analysis of network centralization, but breaking the bimodal affiliation network into two unimodal networks, one of IGOs and the other of states, reveals a nuanced picture. Centralization in the world polity appears to result primarily from the IGO mode: the network of IGOs is increasingly centralized around active IGOs that share member states with many other IGOs. On the other hand, the network of states has become less centralized around central states that have IGO memberships in common with many other states. The centralization results for the unimodal networks suggest that world polity theory explains the structure of the interstate side of the network, while world systems theory accounts for the IGO side. Future research should explore the extent to which this pattern of changing centralization is consistent with the conflict-centered model of the world polity that builds on insights from both the world systems and world polity approaches (Beckfield 2003). 
The world civilizations approach of Huntington (1996) also receives support from the results. Among state dyads, there is a significant association between alignment with the same civilization and the number of IGO co-memberships, both in 1950 and 2000. It seems that cultural (or geographical) cleavages do correspond to political cleavages, as states from like cultures (and places) join the same organizations while states from different cultures (and places) join different ones. In the world polity, common cultures and proximate places do indeed appear to be coming together. Still, the distinction between presence/absence and strength of ties again appears in the world civilization results. Civilizational commonality is associated with having at least one shared IGO membership in 1950, but not in 2000. This indicates that world civilization strengthens political bonds, but that it may not explain their absence.

While I highlight the theoretical implications and contributions of this study, I also acknowledge its limitations. First, although one strength of the study is its disaggregation of the world polity through a focus on prominent IGOs that comprise a distinct and comparable set of organizations, this focus is also a limitation. Future work should extend the networkanalytic approach employed here to other fields of international organizations, including international nongovernmental organizations (INGOs). Especially fruitful would be examinations of IGOs at the center of the world polity, such as the World Trade Organization (WTO) (Goldman 2001), and analyses of specific global policy scripts (Boyle et al. 2001). Second, while a strength of the study is its comparison of the structure of the world polity across two theoretically-selected time points, its conclusions are necessarily limited to 1950 and 2000. Future work should examine network data taken from a wider range of years. Third, the evolution of the network structure of the world polity only tells part of the complex story of how the world polity has evolved.

Thus, this study highlights several promising areas for future research on the world polity. First, the substantial regionalization of the "world" polity warrants further scrutiny to determine what effects this regionalization has on the creation and diffusion of international norms. Such research would be especially valuable because it could address longstanding questions within the social network literature surrounding the relationship between network structure and network content. For instance, one potentially fruitful line of inquiry could compare the policy scripts of global organizations such as the UN or the OECD to the policy scripts of regional organizations such as the EU. Second, while attention should of course be given to the network of INGOs, further work could be done to disaggregate the field of IGOs and compare the effects of IGO embeddedness across IGO types (Boehmer et al. 2004; Ingram et al. 2005). The recent work on IGOs from international relations and organizations scholars should be used to inform new research on IGOs and INGOs. Such research should address, for instance, the question of whether regional organizations have effects that are consistent or inconsistent with those of universalist organizations, and, thus, have integrative or disintegrative implications for the world polity as a whole.

In sum, this study presents several new findings that advance the sociological literature on the world polity and, more broadly, the social science of political globalization. Focusing on the IGOs that form an essential part of the backbone of the world polity reveals that, even in the context of growing interconnections among dyads of states, the network of IGOs that states "plug in" to is only sparsely interconnected, and the density of interconnections among IGOs has actually decreased over time. The network of IGOs is highly centralized, and has become more so over time. Shared positions in the world system and the world of civilizations predict shared world polity ties, revealing that the world polity has an uneven structure significantly fragmented by material and symbolic conflict. As Anne-Marie Slaughter notes in A New World Order (2004): "if 'global government networks' are in fact only partial government networks, they will ultimately fail" (p. 228). The network analysis of IGOs presented here shows that much work remains to be done before the world polity can be characterized as a globally integrated government network. 
BECKFIELD

Appendix A. Extracts from Data Matrices

\section{$10 \times 10$ Extract of Bimodal 2000 World Polity Network}

States:

$\underline{A} \underline{B} \underline{B} \underline{\mathrm{C}} \underline{\mathrm{G}} \underline{I} \underline{\mathrm{M}} \underline{\mathrm{S}} \underline{\mathrm{U}} \underline{\mathrm{Z}}$

IGOS:

Arab League

Common Market of the Southern Cone

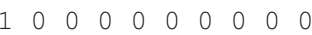

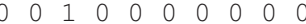

European Union

North American Free Trade Agreement

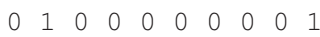

North Atlantic Treaty Organization

$0 \begin{array}{llllllllll}0 & 0 & 0 & 0 & 1 & 0 & 0 & 0 & 0 & 0\end{array}$

$0 \begin{array}{lllllllllllllllllll}0 & 0 & 0 & 0 & 0 & 0 & 1 & 0 & 1 & 0\end{array}$

Organization for African Unity

$0 \begin{array}{llllllllll}0 & 0 & 0 & 0 & 1 & 0 & 0 & 0 & 1 & 0\end{array}$

Organization of American States

$\begin{array}{llllllllll}1 & 1 & 0 & 0 & 0 & 0 & 0 & 0 & 0 & 1\end{array}$

Organization of Petroleum Exporting Countries

$0 \begin{array}{llllllllllllllllll}0 & 0 & 1 & 0 & 0 & 0 & 1 & 0 & 1 & 0\end{array}$

United Nations

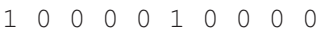

$\begin{array}{llllllllll}1 & 1 & 1 & 1 & 1 & 1 & 1 & 1 & 1 & 1\end{array}$

States: Algeria, Botswana, Brazil, China, Germany, Iran, Mexico, South Korea, United States, Zimbabwe

\section{$10 \times 10$ Extract of Unimodal 2000 IGO Network}

Ara MER $\underline{\text { COm EU }} \underline{\mathrm{NAE}} \underline{\mathrm{NAT}} \underline{\mathrm{OAU}} \underline{\mathrm{OAS}} \underline{\mathrm{OPE}} \underline{\mathrm{UN}}$

Arab League

MERCOSUR

Commonwealth

European Union

NAFTA

NATO

Organization for African Unity

Organization of American States

OPEC

United Nations

$\begin{array}{rrrrrrrrrr}22 & 0 & 0 & 0 & 0 & 0 & 9 & 0 & 7 & 21 \\ 0 & 4 & 0 & 0 & 0 & 0 & 0 & 4 & 0 & 4 \\ 0 & 0 & 53 & 1 & 1 & 2 & 18 & 13 & 0 & 49 \\ 0 & 0 & 1 & 15 & 0 & 11 & 0 & 0 & 0 & 15 \\ 0 & 0 & 1 & 0 & 3 & 2 & 0 & 3 & 0 & 3 \\ 0 & 0 & 2 & 11 & 2 & 19 & 0 & 2 & 0 & 19 \\ 9 & 0 & 18 & 0 & 0 & 0 & 53 & 0 & 3 & 52 \\ 0 & 4 & 13 & 0 & 3 & 2 & 0 & 34 & 1 & 34 \\ 7 & 0 & 0 & 0 & 0 & 0 & 3 & 1 & 11 & 11 \\ 21 & 4 & 49 & 15 & 3 & 19 & 52 & 34 & 11 & 185\end{array}$

$10 \times 10$ Extract of Unimodal 2000 Interstate Network

$\underline{\text { Al }} \underline{\text { Bo }} \underline{\mathrm{Br}} \underline{\mathrm{Ch}} \underline{\mathrm{Ge}} \underline{\underline{\text { Ir }}} \underline{\mathrm{Me}} \underline{\mathrm{SK}} \underline{\mathrm{US}} \underline{\mathrm{Zi}}$

$\begin{array}{lrrrrrrrrrr}\text { Algeria } & 8 & 3 & 2 & 2 & 2 & 3 & 1 & 2 & 2 & 3 \\ \text { Botswana } & 3 & 5 & 2 & 2 & 2 & 1 & 1 & 2 & 2 & 5 \\ \text { Brazil } & 2 & 2 & 7 & 3 & 4 & 1 & 4 & 3 & 5 & 2 \\ \text { China } & 2 & 2 & 3 & 5 & 4 & 1 & 2 & 5 & 5 & 2 \\ \text { Germany } & 2 & 2 & 4 & 4 & 14 & 1 & 3 & 6 & 9 & 2 \\ \text { Iran } & 3 & 1 & 1 & 1 & 1 & 5 & 1 & 2 & 2 & 1 \\ \text { Mexico } & 1 & 1 & 4 & 2 & 3 & 1 & 8 & 3 & 6 & 1 \\ \text { S. Korea } & 2 & 2 & 3 & 5 & 6 & 2 & 3 & 8 & 8 & 2 \\ \text { US } & 2 & 2 & 5 & 5 & 9 & 2 & 6 & 8 & 14 & 2 \\ \text { Zimbabwe } & 3 & 5 & 2 & 2 & 2 & 1 & 1 & 2 & 2 & 6\end{array}$




\section{Appendix B. Extracts from Model Matrices}

\section{$10 \times 10$ Extract of Model World Systems Network}

$\begin{array}{lcccccccccc} & \text { G } & \text { U } & \text { I } & \text { S } & \text { A } & \text { B } & \text { B } & \text { C } & \text { M } & \text { Z } \\ \text { Germany } & 1 & 1 & 1 & 1 & 1 & 1 & 1 & 1 & 1 & 1 \\ \text { United States } & 1 & 1 & 1 & 1 & 1 & 1 & 1 & 1 & 1 & 1 \\ \text { Iran } & 1 & 1 & 0 & 0 & 0 & 0 & 0 & 0 & 0 & 0 \\ \text { South Korea } & 1 & 1 & 0 & 0 & 0 & 0 & 0 & 0 & 0 & 0 \\ \text { Algeria } & 1 & 1 & 0 & 0 & 0 & 0 & 0 & 0 & 0 & 0 \\ \text { Botswana } & 1 & 1 & 0 & 0 & 0 & 0 & 0 & 0 & 0 & 0 \\ \text { Brazil } & 1 & 1 & 0 & 0 & 0 & 0 & 0 & 0 & 0 & 0 \\ \text { China } & 1 & 1 & 0 & 0 & 0 & 0 & 0 & 0 & 0 & 0 \\ \text { Mexico } & 1 & 1 & 0 & 0 & 0 & 0 & 0 & 0 & 0 & 0 \\ \text { Zimbabwe } & 1 & 1 & 0 & 0 & 0 & 0 & 0 & 0 & 0 & 0\end{array}$

\section{$10 \times 10$ Extract of Model World Civilizations Network}

$\begin{array}{lllllllllll} & \text { G } & \text { U } & B & M & B & Z & A & I & C & S \\ \text { Germany } & 1 & 1 & 0 & 0 & 0 & 0 & 0 & 0 & 0 & 0 \\ \text { United States } & 1 & 1 & 0 & 0 & 0 & 0 & 0 & 0 & 0 & 0 \\ \text { Brazil } & 0 & 0 & 1 & 1 & 0 & 0 & 0 & 0 & 0 & 0 \\ \text { Mexico } & 0 & 0 & 1 & 1 & 0 & 0 & 0 & 0 & 0 & 0 \\ \text { Botswana } & 0 & 0 & 0 & 0 & 1 & 1 & 0 & 0 & 0 & 0 \\ \text { Zimbabwe } & 0 & 0 & 0 & 0 & 1 & 1 & 0 & 0 & 0 & 0 \\ \text { Algeria } & 0 & 0 & 0 & 0 & 0 & 0 & 1 & 1 & 0 & 0 \\ \text { Iran } & 0 & 0 & 0 & 0 & 0 & 0 & 1 & 1 & 0 & 0 \\ \text { China } & 0 & 0 & 0 & 0 & 0 & 0 & 0 & 0 & 1 & 1 \\ \text { South Korea } & 0 & 0 & 0 & 0 & 0 & 0 & 0 & 0 & 1 & 1\end{array}$

\section{References}

Bandy, Joe. 2004. "Paradoxes of Transnational Civil Societies under Neoliberalism: The Coalition for Justice in the Maquiladoras." Social Problems 51:410-31.

Barrett, Deborah and Amy Ong Tsui. 1999. "Policy as Symbolic Statement: International Response to National Population Policies." Social Forces 78:213-34.

Beckfield, Jason. 2003. "Inequality in the World Polity: The Structure of International Organization." American Sociological Review 68:401-24.

2006. "European Integration and Income Inequality." American Sociological Review 71:964-85.

Boehmer, Charles, Erik Gartzke, and Timothy Nordstrom. 2004. “Do Intergovernmental Organizations Promote Peace?" World Politics 57:1-38.

Boli, John and George M. Thomas. 1997. “World Culture in the World Polity: A Century of International Non-Governmental Organization." American Sociological Review 62:171-90.

—, eds. 1999a. Constructing World Culture: International Nongovernmental Organizations Since 1875. Stanford, CA: Stanford University Press.

- 1999b. "INGOs and the Organization of World Culture." Pp. 13-49 in Constructing World Culture: International Nongovernmental Organizations Since 1875, edited by John Boli and George M. Thomas. Stanford, CA: Stanford University Press.

Boli, John, Thomas A. Loya, and Teresa Loftin. 1999. "National Participation in World-Polity Organization." Pp. 50-77 in Constructing World Culture: International Nongovernmental Organizations Since 1875, edited by John Boli and George M. Thomas. Stanford, CA: Stanford University Press.

Bollen, Kenneth A. 1983. "World System Position, Dependency, and Democracy: The Cross- National Evidence." American Sociological Review 48:468-79. 
Bollen, Kenneth A. and Stephen J. Appold. 1993. "National Industrial Structure and the Global System." American Sociological Review 58:283-301.

Borgatti, Stephen P., Martin G. Everett, and Linton C. Freeman. 2002. UCINET for Windows: Software for Social Network Analysis. Lexington, KY: Analytic Technologies.

Boswell, Terry and Christopher Chase-Dunn. 2000. The Spiral of Capitalism and Socialism: Toward Global Democracy. Boulder, CO: Lynne Rienner.

Boyle, Elizabeth Heger, Fortunata Songora, and Gail Foss. 2001. "International Discourse and Local Politics: Anti-Female-Genital-Cutting Laws in Egypt, Tanzania, and the United States." Social Problems 48:524-44.

Bratton, Michael. 1989. "Beyond the State: Civil Society and Associational Life in Africa." World Politics 41:407-30.

Breiger, Ronald L. 1974. “The Duality of Persons and Groups." Social Forces 53:181-90.

Burt, Ronald S. 1992. Structural Holes. Cambridge, MA: Harvard University Press.

Central Intelligence Agency, United States (CIA). 2002. The World Factbook. Washington, DC: Central Intelligence Agency.

Chase-Dunn, Christopher and Peter Grimes. 1995. "World systems Analysis." Annual Review of Sociology 21:387-417.

DiMaggio, Paul J. and Walter W. Powell. 1983. "The Iron Cage Revisited: Institutional Isomorphism and Collective Rationality in Organizational Fields." American Sociological Review 48:147-60.

Europa Publications. 1961. The Europa Yearbook. London, UK: Europa Publications Limited.

Europa Publications. 2000. The Europa Yearbook. London, UK: Europa Publications Limited.

Feld, Werner J. and Robert S. Jordan. 1988. International Organizations: A Comparative Approach. 2d ed. New York: Praeger.

Fisher, Dana R., Kevin Stanley, David Berman, and Gina Neff. 2005. "How Do Organizations Matter? Mobilization and Support for Participants at Five Globalization Protests." Social Problems 52:102-21.

Fligstein Neil. 2001. The Architecture of Markets. Princeton, NJ: Princeton University Press.

. 2007. "The Creation of Social, Economic, and Political Arenas in Europe." University of CaliforniaBerkeley, Berkeley, CA. Unpublished manuscript.

Fligstein, Neil and Frederic Merand. 2002. "Globalization or Europeanization? Evidence on the European Economy Since 1980." Acta Sociologica 45:7-22.

Florini, Ann M., ed. 2000. The Third Force: The Rise of Transnational Civil Society. Washington, DC: Brookings Institution Press.

Frank, David John. 1999. "The Social Bases of Environmental Treaty Ratification, 1900-1990." Sociological Inquiry 69:523-50.

Frank, David John, Ann Hironaka, and Evan Schofer. 2000. “The Nation-State and the Natural Environment over the Twentieth Century." American Sociological Review 65: 96-1 16.

Frank, David John, Ann Hironaka, John W. Meyer, Evan Schofer, and Nancy Brandon Tuma. 1999. “The Rationalization and Organization of Nature in World Culture." Pp. 81-99 in Constructing World Culture: International Nongovernmental Organizations Since 1875, edited by John Boli and George M. Thomas. Stanford, CA: Stanford University Press.

Frank, David John and Elizabeth H. McEneaney. 1999. "The Individualization of Society and the Liberalization of State Policies on Same-Sex Sexual Relations, 1984-1995." Social Forces 77:911-44.

Freeman, Linton C. 1979. "Centrality in Social Networks: Conceptual Clarification." Social Networks 1:215-39.

Galaskiewicz, Joseph. 1985. Social Organization of an Urban Grants Economy. New York: Academic Press.

Gartzke, Erik, Quan Li, and Charles Boehmer. 2001. "Investing in the Peace: Economic Interdependence and International Conflict." International Organization 55:391-438.

Goldman, Michael. 2001. "Constructing an Environmental State: Eco-Governmentality and Other Transnational Practices of a 'Green' World Bank." Social Problems 48:499-523.

Granovetter, Mark S. 1973. "The Strength of Weak Ties." American Journal of Sociology 78:1360-80.

Guillén, Mauro F. 2001. “Is Globalization Civilizing, Destructive, or Feeble? A Critique of Five Key Debates in the Social Science Literature." Annual Review of Sociology 27:235-60.

Hafner-Burton, Emilie N. and Alexander H. Montgomery. 2006. "Power Positions: International Organizations, Social Networks, and Conflict." Journal of Conflict Resolution 50:3-27.

Hafner-Burton, Emilie N. and Kiyoteru Tsutsui. 2005. "Human Rights in a Globalizing World: The Paradox of Empty Promises." American Journal of Sociology 1 10:1373-1411.

Hall, Peter A. and Rosemary C. R. Taylor. 1996. "Political Science and the Three New Institutionalisms." Political Studies 44:936-57. 
Hardt, Michael and Antonio Negri. 2000. Empire. Cambridge, MA: Harvard University Press.

Held, David, Anthony McGrew, David Goldblatt, and Jonathan Perraton. 1999. Global Transformations: Politics, Economics, and Culture. Stanford, CA: Stanford University Press.

Henisz, Witold J., Bennet A. Zelner, and Mauro F. Guillén. 2005. "The Worldwide Diffusion of MarketOriented Infrastructure Reform, 1977-1999." American Sociological Review 70:871-97.

Hirst, P. and G. Thompson. 1996. Globalization in Question. London: Polity Press.

Huntington, Samuel P. 1996. The Clash of Civilizations and the Remaking of World Order. New York: Simon 8 Schuster.

Inglehart, Ronald and Wayne E. Baker. 2000. "Modernization, Cultural Change, and the Persistence of Traditional Values." American Sociological Review 65:19-51.

Ingram, Paul, Jeffery Robinson, and Marc Busch. 2005. “The Intergovernmental Network of World Trade: IGO Connectedness, Governance and Embeddedness." American Journal of Sociology $111: 824-58$.

Jacobson, Harold K. 1979. Networks of Interdependence: International Organizations and the Global Political System. New York: Knopf.

Jacobson, Harold K., William M. Reisinger, and Todd Mathers. 1986. "National Entanglements in International Governmental Organizations." American Political Science Review 80:141-59.

Kadushin, Charles. 1995. "Friendship among the French Financial Elite." American Sociological Review 60:202-21.

Katzenstein, Peter J. 2005. A World of Regions: Asia and Europe in the American Imperium. Ithaca, New York: Cornell University Press.

Katzenstein, Peter J., Robert O. Keohane, and Stephen D. Krasner. 1998. “International Organization and the Study of World Politics." International Organization 52:645-86.

Kentor, Jeffrey. 2000. Capital and Coercion: The Economic and Military Processes that Have Shaped the World Economy 1800-1990. New York: Garland.

Kim, Kyungmo and George A. Barnett. 2000. "The Structure of the International Telecommunications Regime in Transition: A Network Analysis of International Organizations." International Interactions 26:91-127.

Kim, Sangmoon and Eui-Hang Shin. 2002. "A Longitudinal Analysis of Globalization and Regionalization in International Trade: A Social Network Approach." Social Forces 81:445-68.

Krasner, Stephen D. 1985. Structural Conflict: The Third World Against Global Liberalism. Berkeley: University of California Press.

Meyer, John. 2000. "Globalization: Sources and Effects on National States and Societies." International Sociology 15:233-48.

Meyer, John, John Boli, George Thomas, and Francisco Ramirez. 1997. "World Society and the NationState." American Journal of Sociology 103:144-81.

Meyer, John W., David John Frank, Ann Hironaka, Evan Schofer, and Nancy Brandon Tuma. 1997. “The Structuring of a World Environmental Regime, 1870-1990." International Sociology 51:623-51.

Mizruchi, Mark S. 1990. "Determinants of Political Opposition Among Large American Corporations." Social Forces 68:1065-88.

Moon, Rennie. 2003. From Charity to Human Right: Discourse and Global Expansion of Health and Health Education, 1650-1997. Stanford, CA: Stanford University. Unpublished monograph.

Oneal, John and Bruce Russett. 1997. "The Classical Liberals Were Right: Democracy, Interdependence and Conflict, 1950-1985." International Studies Quarterly 41:267-93.

- 2001. "Clear and Clean: The Fixed Effects of the Liberal Peace." International Organization 55:469-85.

O'Riain, Sean. 2000. "States and Markets in an Era of Globalization." Annual Review of Sociology 26:187-213.

Padgett, John F. and Christopher K. Ansell. 1993. "Robust Action and the Rise of the Medici, 14001434." American Journal of Sociology 98:1259-1319.

Pevehouse, Jon, Timothy Nordstrom, and Kevin Warnke. 2004. "The Correlates of War 2 International Governmental Organizations Data Version 2.0." Conflict Management and Peace Science 21:101-19.

Ramirez, Francisco O., Yasemin Soysal, and Suzanne Shanahan. 1997. "The Changing Logic of Political Citizenship: Cross-National Acquisition of Women's Suffrage Rights, 1890 to 1990." American Sociological Review 62:735-45.

Rice, Andrew E. and Cyril Ritchie. 1995. "Relationships between International Non-governmental organizations and the United Nations." Transnational Associations 47:254-65.

Russett, Bruce, John Oneal, and David Davis. 1998. "The Third Leg of the Kantian Tripod for Peace: International Organizations and Militarized Disputes, 1950-1985." International Organization 52:441-67. 
Sassen, Saskia. 1996. Losing Control? Sovereignty in an Age of Globalization. New York: Columbia University Press.

Schafer, Mark J. 1999. "International Nongovernmental Organizations and Third World Education in 1990: A Cross-National Study." Sociology of Education 72:69-88.

Schofer, Evan and Ann Hironaka. 2005. "The Effects of World Society on Environmental Protection Outcomes." Social Forces 84:25-47.

Schofer, Evan and John W. Meyer. 2005. "The Worldwide Expansion of Higher Education in the Twentieth Century." American Sociological Review 70:898-920.

Shanks, Cheryl, Harold K. Jacobson, and Jeffrey H. Kaplan. 1996. "Inertia and Change in the Constellation of International Governmental Organizations, 1981-1992." International Organization 50:593627.

Shaw, Timothy M. 1991. "Reformism, Revisionism, and Radicalism in African Political Economy during the 1990s." The Journal of Modern African Studies 29:191-212.

Simmons, Beth, Frank Dobbin, and Geoffrey Garrett. 2006. "Introduction: The International Diffusion of Liberalism." International Organization 60:781-810.

Simmons, Beth and Zachary Elkins. 2005. "On Waves, Clusters and Diffusion: A Conceptual Framework." Annals of the American Academy of Political and Social Science 598:33-51.

Singer, J. David and Michael Wallace. 1970. "Intergovernmental Organization and the Preservation of Peace, 1816-1964: Some Bivariate Relationships." International Organization 24:520-47.

Slaughter, Anne-Marie. 2004. A New World Order. Princeton, NJ: Princeton University Press.

Smith, David A. 2001. "Globalization and Social Problems." Social Problems 48:429-34.

Smith, David A., Dorothy J. Solinger, and Steven C. Topik, eds. 1999. States and Sovereignty in the Global Economy. London and New York: Routledge.

Smith, Jackie. 2000. “Review of Constructing World Culture: International Nongovernmental Organizations Since 1875." Social Forces 78:1573-75.

Smith, Jackie and Dawn Wiest. 2005. "The Uneven Geography of Global Civil Society: National and Global Influences on Transnational Association." Social Forces 84:621-47.

Snijders, Tom A. B. and Stephen P. Borgatti. 1999. "Non-Parametric Standard Errors and Tests for Network Statistics." Connections 22:61-70.

Snyder, David and Edward L. Kick. 1979. "Structural Position in the World System and Economic Growth 1955-1970: A Multiple-Network Analysis of Transnational Interactions." American Journal of Sociology 84:1096-1 126.

Steinberg, S. H., ed. 1950. The Statesman's Yearbook. New York: Macmillan.

Stinchcombe, Arthur L. 1997. "On the Virtues of the Old Institutionalism." Annual Review of Sociology 23:1-18.

Strang, David and John W. Meyer. 1993. "Institutional Conditions for Diffusion." Theory and Society 22:487-511.

Strange, Susan. 1996. The Retreat of the State: The Diffusion of Power in the World Economy. New York: Cambridge University Press.

Thelen, Kathleen. 1999. "Historical Institutionalism in Comparative Politics." Annual Review of Political Science 2:369-404.

Thomas, George M. and John W. Meyer. 1984. "The Expansion of the State." Annual Review of Sociology $10: 461-82$.

True, Jacqui and Michael Mintrom. 2001. "Transnational Networks and Policy Diffusion: The Case of Gender Mainstreaming." International Studies Quarterly 45:27-57.

Turner, Barry, ed. 2000. The Statesman's Yearbook. New York: St. Martin's Press.

Union of International Associations (UIA). 2000. Yearbook of International Organizations 2000/2001. Munich, Germany: KG Saur.

Wallace, Michael and J. David Singer. 1970. "Intergovernmental Organizations in the Global System, 1815-1964: A Quantitative Description." International Organization 24:239-87.

Wasserman, Stanley and Katherine Faust. 1994. Social Network Analysis: Methods and Applications. Cambridge, UK: Cambridge University Press.

World Bank. 2002. World Development Indicators [CD-ROM]. Washington, DC: World Bank. 